\title{
IMPLEMENTASI WEBSITE PROMOSI DAN PENJUALAN PADA ASOSIASI PEDAGANG SEPATU DAN TAS KOTA PADANG
}

\author{
Sularno 1), Anggraini, ${ }^{2)}$, Razi, ${ }^{2)}$ \\ ${ }^{1}$ Program Studi Sistem Informasi, Universitas Dharma Andalas \\ email : soelarno@unidha.ac.id \\ ${ }^{2}$ Program Studi Sistem Informasi, Universitas Dharma Andalas \\ email: bontetga@unidha.ac.id \\ 3 Program Studi Sistem Informasi, Universitas Dharma Andalas \\ email: razi@unidha.ac.id
}

\begin{abstract}
Association of Bag and Shoes Traders in Padang City has difficulties in the field of data processing for the purchase and sale of goods. Because the processing of this data still uses Microsoft Excel so that to find the necessary files need to be long and also is data redundancy on each file, then an information system is used to provide fast and accurate data.

Research conducted directly using interview techniques, then by giving books, literature related to the problems discussed. After the data is collected, the data are grouped and analyzed using the Unified Modeling Language (UML). The results of the analysis are applied in a phpmysql-based data processing information system application program.

By designing a new system, making reports related to sales information can be made quickly, precisely and can be solved with errors.
\end{abstract}

Keywords: Trader, UML, File, Information System

\section{PENDAHULUAN}

Pada masa sekarang ini perkembangan ilmu pengetahuan sudah sangat maju terutama dalam bidang teknologi. Salah satu dari kemajuan tersebut adalah telah menciptakan suatu alat yang disebut komputer. Komputer sebagai sarana penyimpan dan pengolahan data tidak dapat lagi disangkal keberadaannya. Perkantoraan dan perusahaan-perusahaan sudah semakin banyak mengunakan jasa komputer dalam proses pengolahan data terutama dalam usaha peningkatan produktivitas dan efesiensi kerja.

Pada perusahaan yang ingin bersaing dan mengejar keuntungan yang besar, maka komputer merupakan alat bantu yang sangat bermanfaat dalam proses kegiatan perusahaan, termasuk proses penyediaan informasi. Informasi merupakan sumber data yang diperlukan oleh berbagai pihak di perusahaan, baik pihak intern maupun pihak ekstern perusahaan, salah satu informasi yang sangat penting adalah sistem informasi penjualan.

Assosiasi Pedagang Tas Dan Sepatu Kota Padang mengalami kesulitan dalam bidang pengolahan data pembelian dan penjualan barang. Karena pengolahan data tersebut masih mengunakan microsoft excel sehingga untuk menemukan sebuah file bila dibutuhkan perlu waktu yang lama dan juga terdapat redudansi data pada tiap-tiap file, maka diterapkan suatu sistem informasi guna dapat menyajikan data-data yang cepat dan akurat.

Dan untuk membantu menciptakan suatu sistem informasi penjualan barang yang lebih tepat, cepat dan akurat, maka penulis berkeinginan untuk menuangkan permasalahan ini menjadi sebuah karya ilmiah dalam bentuk laporan penelitian dengan memilih PHPMysql sebagai 
bahasa pemrograman yang diterapkan dengan judul "IMPLEMENTASI WEBSITE PROMOSI DAN PENJUALAN PADA ASOSIASI PEDAGANG SEPATU DAN TAS KOTA PADANG".

\section{LANDASAN TEORI}

Sistem informasi bukan merupakan hal yang baru. Yang baru adalah komputerisasinya. Sebelum ada komputer, teknik penyaluran informasi yang memungkinkan manajer merencanakan serta mengendalikan sudah ada.

\subsection{Pengertian Sistem}

Sistem pada dasarnya adalah sekelompok unsur yang sangat erat hubungannya satu dengan yang lain, yang berfungsi bersama-sama untuk mencapai suatu tujuan (Tata Sutabri,2012:6)

\subsubsection{Pengertian Subsistem}

Sebuah subsistem sebenarnya merupakan bagian dari subsitem itu sendiri. suatu sistem dapat terdiri dari bagian-bagian sistem atau subsistem. Subsistem perangkat keras dapat teridiri dari alat masukan, alat pemroses alat keluaran, dan media penyimpanan. Subsistem tersebut akan saling berinteraksi sedemikian rupa sehingga tercapai suatu kesatuan yang terpadu dan terintegrasi.

Norman L. Enger mengatakan dalam bukunya bahwa subsistem adalah serangkaian kegiatan yang dapat ditentukan identitasnyayang berhubungan dalam suatu sistem. Sedangkan Gordon B. Davis dalam bukunya mengatakan bahwa sistem terbagi atas beberapa faktor atau unsur beberapa sub sistem.

\subsubsection{Daur Hidup Sistem}

Siklus Hidup Sistem (system life cyrcle) adalah proses evolusioner yang diikuti dalam penerapan sistem atau subsistem infrormasi berbasis komputer. Siklus hidup sistem terdiri dari serangkaian tugas yang mengikuti langkah-langkah pendekatan sistem, karena tugas-tugas tersebut mengikuti pola yang teratur dan dilakukan secara top down(Tata Sutabri,2012:20).

Tahapan daur hidup sistem dapat dilihat pada gambar berikut :

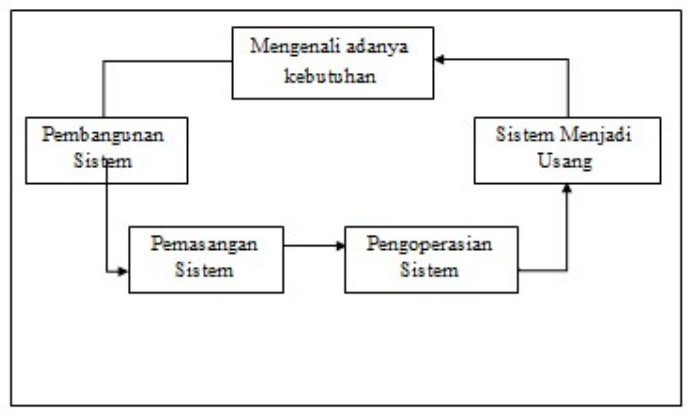

Gambar 2.1.2 : Daur Hidup Sistem

\subsection{Pengertian Informasi}

Informasi adalah data yang telah diklasifikasikan atau diolah atau diinterpretasikan untuk digunakan dalam proses pengambilan keputusan.sistem pengolahan informasi akan mengolah data menjadi informasi atau mengolah data dari bentuk tak guna menjadi berguna bagi yang menerimanya( Tata Sutabri,2012:22).

Informasi dapat dikelompokkan menjadi tiga bagian, yaitu :

a. Informasi Srategis. Informasi ini digunakan untuk mengambil keputusan jangka panjang, yang mencakup informasi eksternal, rencana perluasan perusahaan, dan sebagainya.

b. Informasi Taktis. Informasi ini dibutuhkan untuk mengambil keputusan jangka menengah.

c. Informasi Teknis. Informasi ini dibutuhkan untuk keperluan operasional sehari-hari.

\subsubsection{Fungsi dan Siklus Informasi}

Fungsi utama informasi adalah menambah pengetahuan atau mengurangi ketidakpastian pemakai informasi. Informasi yang disampaikan kepada pemaka mungkin merupaka hasil dari data yang dimasukkan ke dalam pengolahan. Akan tetapi dalam kebanyakan 
pengambilan keputusan yang kompleks, informasi hanya dapat menambahkemungkinan kepastian atau mengurangi bermacam-macam pilihan.

Data diolah melalui suatu model sistem informasi, enerima akan menerima informasi tersebut untuk membuat suatu keputusan dan melakukan tindakan yang akan mengakibatkan munculnya sejumlah data lagi. Data tersebut akan ditangkapsebagai input, diproses kembali lewat suatu model, dan seterusnya hingga membentuk suatu siklus. Siklus inilah yang disebut siklus informasi (information cyrcle) yang digambarkan sebagai berikut :

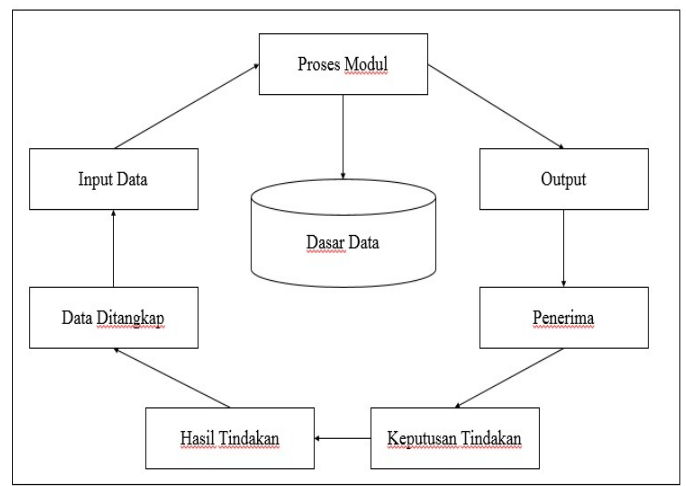

Gambar 2.2.1 Siklus Informasi

(Sumber : Analisis Sistem Informasi, Tata Sutabri,2012:26)

\subsection{Pengertian Sistem Informasi}

Sistem Informasi adalah suatu sistem didalam suatu organisasi yang mempertemukan kebutuhan pengolahan transaksi harian yang mendukung fungsi operasi organisasi yang bersifat manajerial dengan kegiatan strategi dari suatu organisasi untuk dapat menyediakan laporan-laporan yang diperlukan oleh pihak luar tertentu ( Tata Sutabri,2012:38).

Sumber lain menyebutkan bahwa sistem informasi adalah cara yang terorganisir untuk mengumpulkan, memasukkan, dan memproses data dan menyimpannya, mengelola, mengontrol dan melaporkannya sehingga dapat mendukung perusahaan atau organisasi untuk mencapai tujuan (Rudy Tantra, 2012:2).

\subsubsection{Siklus Hidup Pengembangan Sistem}

Siklus pengembangan sistem atau disebut juga System Development Life Cycle (SDLC) adalah proses mengembangkan atau mengubah suatu sistem perangkat lunak dengan menggunakan model-model dan metodologi yang digunakan orang untuk mengmebangkan sistem-sistem perangkat lunak sebelumnya, dengan best practice atau cara-cara yang sudah teruji baik ( Rosa A.S.-M. Shalahuddin,2011:24).

Pada awal pengembangan perangkat lunak, para pembuat program langsung melakukan pengkodean perangkat lunak tanpa menggunakan prosedur atau tahapan pengembangan perangkat lunak. Dan ditemuilah kendalakendala seiring dengan pengembangan sistem perangkat lunak pada skala yang semakin besar.

\subsection{Unified Modelling Language (UML)}

Pada perkembangan teknologi perangkat lunak, diperlukan adanya bahasa yang digunakan untuk memodelkan perangkat lunak yang akan dibuat dan perlu adanya standarisasi agar orang dapat mengerti pemodelan perangkat lunak.

Unified Modeling Language merupakan bahasa visual untuk pemodelan dan komunikasi mengenai sebuah sistem dengan menggunakan diagram dan teks-teeks pendukung ( Rosa

A.S.-M. Shalahuddin,2011:118).

Dalam arti lainnya, UML juga dapat didefinisikan sebagai sebuah standarisasi bahasa pemodelan untuk membangun perangkat lunak yang dibangun menggunakan teknik pemrograman berorientasi objek.

\subsection{Data}

Data adalah catatan atas kumpulan fakta. Data merupakan bentuk jamak dari datum, berasal dari bahasa Latin yang 
berarti "sesuatu yang diberikan". Dalam penggunaan sehari-hari data berarti suatu pernyataan yang diterima secara apa adanya. Pernyataan ini adalah hasil pengukuran atau pengamatan suatu variabel yang bentuknya dapat berupa angka, kata-kata, atau citra.

Dalam keilmuan (ilmiah), fakta dikumpulkan untuk menjadi data. Data kemudian diolah sehingga dapat diutarakan secara jelas dan tepat sehingga dapat dimengerti oleh orang lain yang tidak langsung mengalaminya sendiri, hal ini dinamakan deskripsi. Pemilahan banyak data sesuai dengan persamaan atau perbedaan yang dikandungnya dinamakan klasifikasi.

\subsection{Pengolahan data}

Data dapat bersifat numeris (data angka) : laporan penjualan, laporan persediaan, nilai test, atau dapat juga bersifat non numeris : nama, alamat pelanggan, gambar dll.

Pengolahan Data adalah manipulasi data agar menjadi bentuk yang lebih berguna. Pengolahan data ini tidak hanya berupa perhitungan numeris tetapi juga operasi-operasi seperti klasifikasi data dan perpindahan data dari satu tempat ke tempat lain. Secara umum, kita asumsikan bahwa operasi-operasi tersebut dilaksanakan oleh beberapa tipe mesin atau komputer, meskipun beberapa diantaranya dapat juga dilakukan secara manual.

\subsection{Database}

Sistem basis data adalah sistem terkomputerisasi yang tujuan utamanya adalah memelihara data yang sudah diolah atau informasi dan membuat informasi tersedia saat dibutuhkan. Pada intinya basia data adalah mediantuk menyimpan data agar dapat diakses dengan mudah dan cepat(Rosa A.S.M.Shalahuddin,2011).

\subsection{Konsep Dasar MySQL dan Pemrograman PHP}

Database MySQL dan

Pemrograman PHP merupakan suatu bentuk produk dari open source yang gratis dan dapat digunakan oleh siapapun tanpa ada membayar lisensi dari produk tersebut. Pada bagian ini akan dibahas tentang konsep Database MySQL dan Dasar Pemrograman PHP untuk mendukung aplikasi yang dibuat.

\subsubsection{Sekilas Mengenai MySQL}

MySQL adalah Relational Database Management Sistem (RDBMS) yang didistribusika secara gratis di bawah licensi GPL (GeneralPublic License). Dimana setiap orang bebas untuk menggunakan MySQL, namun tidak boleh dijadikan produk turunan yang bersifat close source atau komersial.MySQL sebenarnya merupakan turunan salah satu konsep utama dalam database sejak lama yaitu, SQL (Structured Query Language). SQLadalah sebuah konsep pengoperasian database, terutam untuk pemilihan/seleksi dan pemasukan data, yang memungkinkan pengoperasian data dikerjakan dengan mudah secara otomatis. Keandalan suatu sistem database (DBMS) dapat diketahui dari cara kerja optimizer-nya dalam melakukan proses perintah perintah SQL, yang dibuat oleh user maupun programprogram aplikasinya. Sebagai database server, MySQL dapat dikatakan lebih unggul dibandingkan database server lainnya dalam query data. Hal ini terbukti untuk query yang dilakukan oleh single user, kecepatan query MySQL bisa sepuluh kali lebih cepat dari PostgreSQL dan lima kali lebih cepat dibandingkan Interbase. Kemampuan yang cukup menakjubkan untuk sebuah software gratisan.

MySQL adalah satu dari sekian banyak sistem database, merupakan terobosan solusi yang tepat dalam aplikasi database. Didukung oleh ribuan bahkan 
jutaan komunitas pengguna di internet yang siap membantu. Selain itu juga tersedia mailing list dan homepage khusus yang memberikan tutorial serta dokumen lengkap.

\subsubsection{Sekilas Tentang PHP}

PHP adalah salah satu bahasa pemrograman yang berjalan dalam sebuah webserver dan berfungsi sebagai pengolah data pada sebuah server (Madcoms,2012:206).

Bahasa ini memungkinkan para pembuat aplikasi web menyajikan halaman HTML dinamis dan interaktif dengan cepat dan mudah, yang dihasilkan server. PHP juga dimaksudkan untuk mengganti teknologi lama seperti CGI (Common Gateway Interface).

\subsection{Konsep Tentang Internet}

Internet (kependekan dari
interconnection-networking) adalah

Jaringan computer yang menghubungkan antar jaringan secara global, internet dapat juga disebut jaringan dalam suatu jaringan yang luas. Seperti halnya jaringan computer local maupun jaringan computer area, internet juga menggunakan protocol komunikasi yang sama yaituTransmission Control Protocol/Internet Protocol Suite (TCP/IP) (Alexander F.K. Sibero, 2011:10).

\subsubsection{Pengertian Website}

Website atau sering disingkat dengan istilah situs adalah sejumlah halaman web yang memiliki topik saling terkait, terkadang disertai pula dengan berkas-berkas gambar, video, atau jenisjenis berkas lainnya. Sebuah situs web biasanya ditempatkan setidaknya pada sebuah server web yang dapat diakses melalui jaringan seperti internet, ataupun jaringan wilayah lokal (LAN) melalui alamat internet yang dikenali sebagai URL. Gabungan atas semua situs yang dapat diakses publik di internet disebut pula sebagai WWW. Sebuah halaman web merupakan berkas yang ditulis sebagai berkas teks biasa (plain text) yang diatur dan dikombinasikan sedemikian rupa dengan instruksi-instruksi berbasis HTML, atau XHTML, kadang-kadang pula disisipi dengan sekelumit bahasa skrip. Berkas tersebut kemudian diterjemahkan oleh peramban web dan ditampilkan seperti layaknya sebuah halaman pada monitor komputer.

\subsubsection{Web Server}

Web server adalah sebuah komputer yang terdiri dari perangkat keras dan perangkat lunak(Alexander F.K. Sibero, 2011:11). Secar bentuk fisik dan cara kerjanya, perangkat keras web server tidak berbeda denga computer pada umumnya. Yang membedakan adalah kapasitas dan kapabilitasnya. Perbedaantersebut karena web server bekerja sebagai penyedia layanan yang diakses oleh banyak pengguna, sehingga dibutuhkan kapasitas dan kapabilitas yang besar dibanding PC.

\subsubsection{Web Browser}

Web browser adalah aplikasi perangkat lunak yang digunakan untukmengambil dan menyajikan sumber informasi web. Sebuah sumber informasi diidentifikasi dengan Pengidentifikasi Sumber Seragam (Uniform Resource Identifier) yang dapat berupa halaman web, gambar, video, atau jenis konten lainnya(Alexander F.K. Sibero, 2011:12).

\section{METODE PENELITIAN}

Untuk mencapai keakuratan dan ketelitian data serta informasi dalam penelitian ini, maka pengumpulan data di lakukan dengan 3 cara :

1. Penelitian lapangan (Field Research)

Penelitian ini dilakukan untuk mendapatkan data secara langsung dari Asosiasi Pedagang Sepatu dan Tas dengan melakukan Observasi dan wawancara langsung ke instansi serta 
pada pihak - pihak yang terkait sehingga data yang dimuat dalam laporan ini nyata kebenarannya.

\section{Penelitian Perpustakaan (Library Research)}

Penelitian ini dilakukan dengan membaca buku - buku literature,diktat kuliah, buku - buku yang berhubungan dengan tema skripsi ini, yang di jadikan sebagai bahan dalam melakukan penelitian dan dalam penulisan skripsi.

3. Penelitian Laboratorium (Laboratory Research)

Penelitian yang didukung perangkat komputer sebagai alat bantu dalam percobaan penyelesaian masalah. Data yang akan digunakan dalam penyusunan sistem informasi berbasis komputer harus diolah dengan program aplikasi yang sesuai dengan kebutuhan pemakai, oleh sebab itu penerapan sistem informasi berbasiskan komputer dapat dilakukan dengan menggunakan komputer yang dibutuhkan.

4. Merancang Program aplikasi untuk membantu mengolah data yang di dapat pada saat melakukan penelitian.

5. Adapun spesifikasi hardware dan software yang di gunakan sebagai berikut :

A. Hardware (perangkat keras)

Merupakan komponen secara fisik yang dapat dilihat dan disentuh. Spesifikasi Hardware yang dibutuhkan adalah :

1. Processor intel core 2 duo

2. Flash Disk 4 GB

3. Printer cannon PIXMA iP 1980

4. Memory 2 GB DDR3 dan 320 GB HDD

5. Mouse : Optic Lexron

6. Monitor

7. Laptop

B. Software (perangkat lunak)

1. Sistem Operasi Windows 10

2. Microsoft Office 2007 dan microsoft visio

3. XAMP 1.6.8
Serta Software pendukung lainnya.

\section{HASIL DAN PEMBAHASAN}

\section{Analisa Sistem Yang Sedang Berjalan}

Analisa sistem adalah penguraian sistem yang utuh kedalam bagian-bagian kecil yang sederhana untuk memahami atau mengetahui masalah, hambatan ,kelemahan dan kendala pada sistem lama untuk dicarikan alternatif pemecahan masalahnya sehingga dapat diusulkan perbaikannya. Untuk menganalisa kelemahan-kelemahan yang ada pada sistem yang sedang berjalan salah satu adalah dengan mengidentifikasikan penyebab dari permasalahan yang timbul.

Adapun prosedur dari sistem yang sedang berjalan pada Asosiaasi Pedagang Sepatu dan Tas terdapat kelemahan dan kekurangannya yaitu :

1. Customer 43upper langsung ke Asosiaasi Pedagang Sepatu dan Tas tersebut untuk mengisi data pemesanan produk 43upperware pada Asosiaasi Pedagang Sepatu dan Tas.

2. Data pemesanan customer di periksa dan Administrasi memberikan faktur pemesanan kepada customer untuk bukti pemesanan

Administrasi akan memberikan laporan data pemesanan produk kepada pimpinan.

\section{Dokumen Sistem Yang Berjalan}

Dokumen yang sedang berjalan pada Prosedur yang terjadi pada pemesanan produk tupperware pada Asosiaasi Pedagang Sepatu dan Tas yaitu Katalog.

\section{Analisa Input}

Analisa input diperlukan untuk mengetahui apa saja yang menjadi input dalam penyajian laporan penjualan pada Asosiaasi Pedagang Sepatu dan Tas, sehingga mempermudah dalam penelitian

Analisa Proses 
Berdasarkan input-input di atas kemudian input tersebut diproses untuk proses selanjutnya. Analisa proses bertujuan untuk menjelaskan bagaimana proses yang terjadi untuk menyusun sebuah laporan transaksi pada pemesanan produk tupperware pada Asosiaasi Pedagang Sepatu dan Tas.

Sebagaimana telah dijelaskan sebelumnya bahwa dalam penyusunan laporan pemesanan produk obat dan peralatan pertaniaan pada Asosiaasi Pedagang Sepatu dan Tas masih menggunakan micrososft excel sebagai alat bantu. Proses penyusunan laporan transaksi obat yang dilakukan oleh pemesanan produk obat dan peralatan pertanian pada Asosiaasi Pedagang Sepatu dan Tas ini diawali dari input berupa bukti transaksi yang digunakan sebagai pedoman dalam proses pembuatan laporan transaksi karena memuat data transaksi. Adapun gambarannya adalah, setiap transaksi pengeluaran barang yang terjadi dicatat dalam rekapan transaksi atau dapat juga dikatakan rekapan dari bukti pemesanan. Selanjutnya, data ini sebagai sumber pendapatan beserta pengeluaran yang akan dipakai bendahara dalam pembuatan laporan transaksi.

\section{Usecase Diagram}

Use case Diagram, menggambarkan sekelompok Use cases dan aktor yang disertai dengan hubungan diantaranya. Diagram Use cases ini menjelaskan dan menerangkan kebutuhan atau requirement yang diinginkan user, serta sangat berguna dalam menentukan struktur organisasi dan model dari pada sebuah sistem. Use case diagram dapat sangat membantu bila kita sedang menyusun requirement sebuah sistem, mengkomunikasikan rancangan dengan klien, dan merancang test case untuk semua feature yang ada pada sistem.
Berikut skenario dari pemesanan produk obat dan peralatan pertanian pada Asosiaasi Pedagang Sepatu dan Tas:

1. Customer melakukan browsing pada website untuk melihat informasi dari produk yang di inginkan.

2. Setelah data produk yang di inginkan di temukan customer untuk dapat memesan produk harus mendaftarkan akun nya sebagai member setelah itu baru login ke dalam system.

3. Admin akan mencek data transaksi pemesanan yang dilakukan oleh customer untuk menferifikasi data pemesanan.

4. Setelah itu admin akan memberikan data laporan pemesana produk kepada pimpinan.

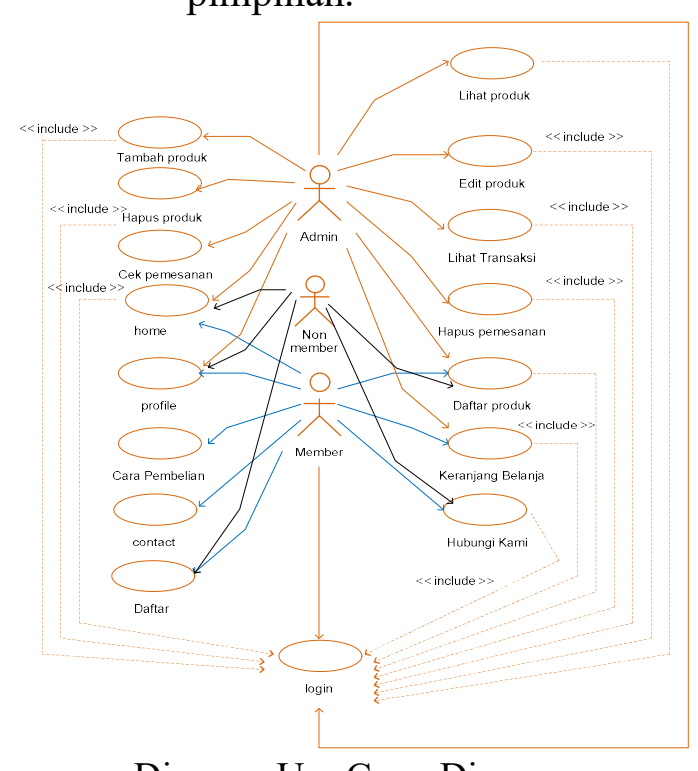

\section{Class Diagram}

Diagram Use Case Diagram

Class diagram menampilkan eksistensi atau keberadaan dari class-class dan hubungan (relationship) dalam desain logikal dari sebuah sistem. Class adalah sebuah spesifikasi yang jika diinstansiasi akan menghasilkan sebuah objek dan merupakan inti dari pengembangan dan desain berorientasi objek. Class menggambarkan keadaan (atribut/properti) suatu sistem, sekaligus 
menawarkan layanan untuk memanipulasi keadaan tersebut (metoda/fungsi).

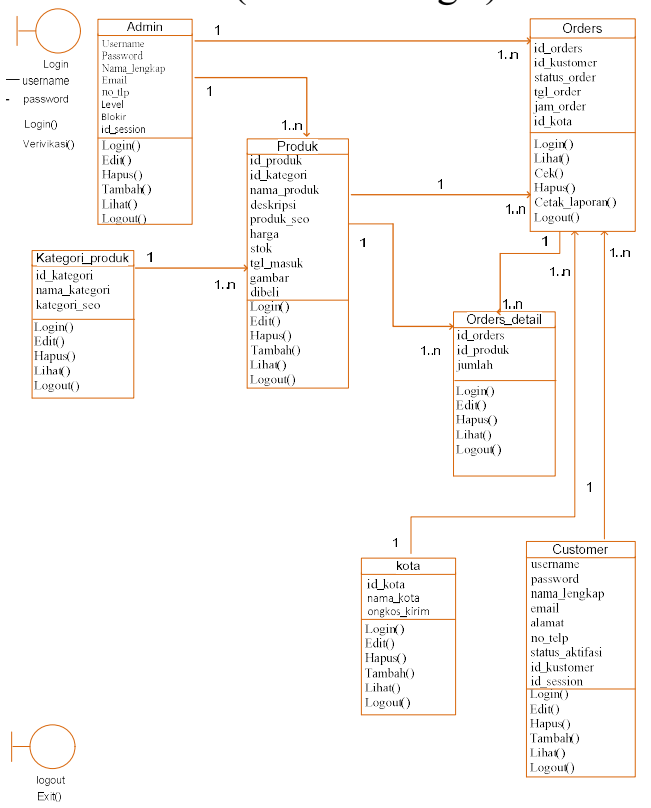

Class Diagram

\section{Menu Halaman Utama}

Perancangan menu halaman utama adalah digunakan untuk mengenalkan menu-menu yang berisi informasi produk obat dan peralatan pertanian yang ada di website. Disain menu halaman utama dapat dilihat pada gambar di bawah ini :

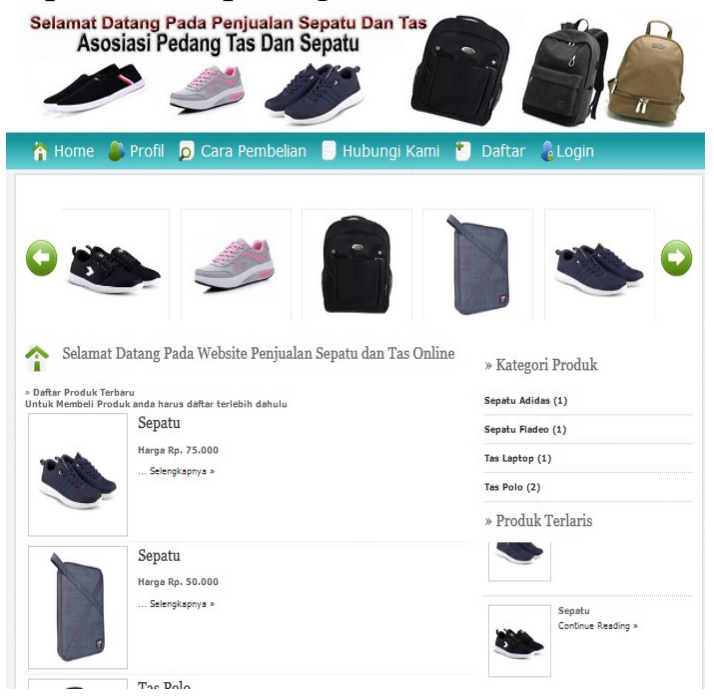

Layout halaman Utama

\section{Menu Daftar Member}

Perancangan menu daftar member adalah dugunakan untuk mendaftar sebagai member sebelum memesan produk. Disain menu daftar member dapat dilihat pada gambar di bawah ini:

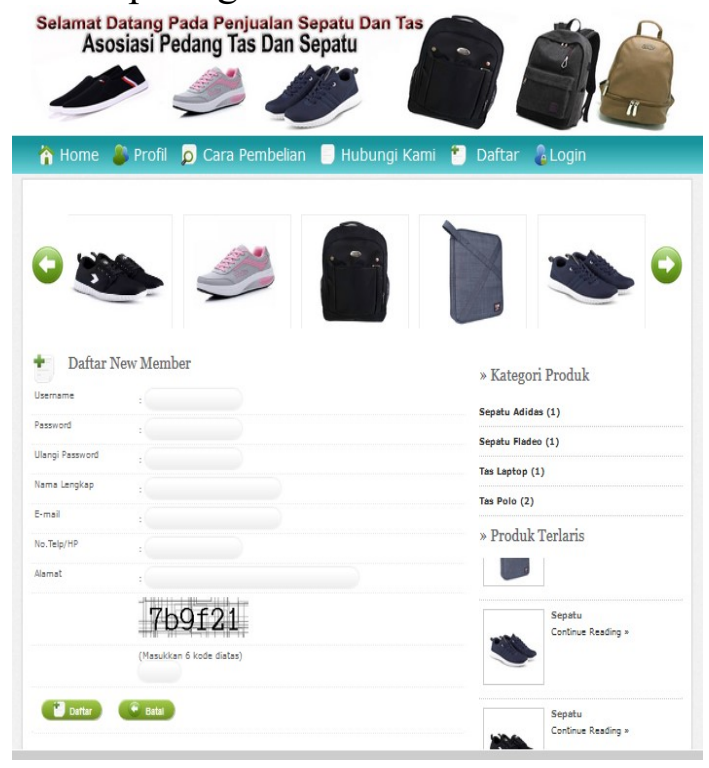

Layout Menu Daftar Member

Menu Keranjang belanja

Perancangan menu keranjang belanja adalah digunakan untuk menampilkan produk yang sudah dipesan atau di order. Disain menu keranjang belanja dapat dilihat pada gambar di bawah ini:

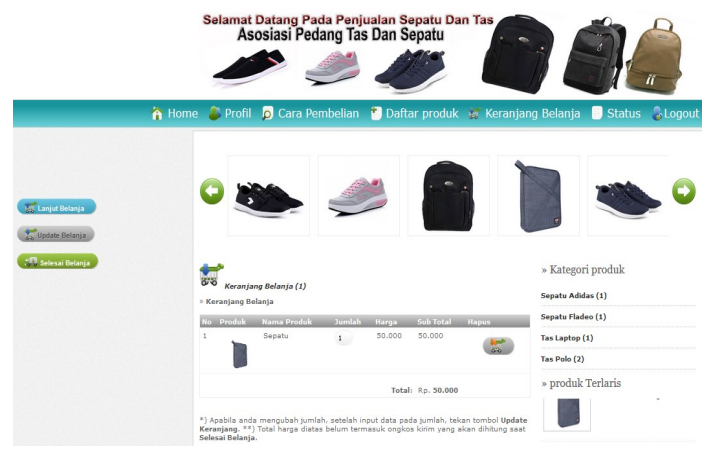

Layout Menu Keranjang belanja

\section{Menu data pemesanan}

Perancangan menu pemesanan adalah digunakan untuk menginputkan data pribadi dan alamat untuk pemesanan produk yang sudah dipesan. Disain data pemesanan dapat dilihat pada gambar di bawah ini: 


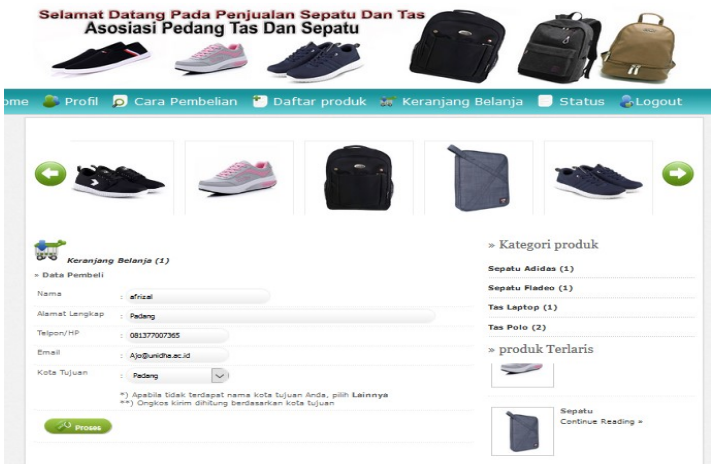

Layout Menu data pemesanan

\section{Menu Status Order}

Perancangan menu status order adalah sebuah fasilitas yang di berikan kepada masyarakat untuk melihat status produk yang sudah di pesan. Disain menu status order dapat dilihat pada gambar 5.34:

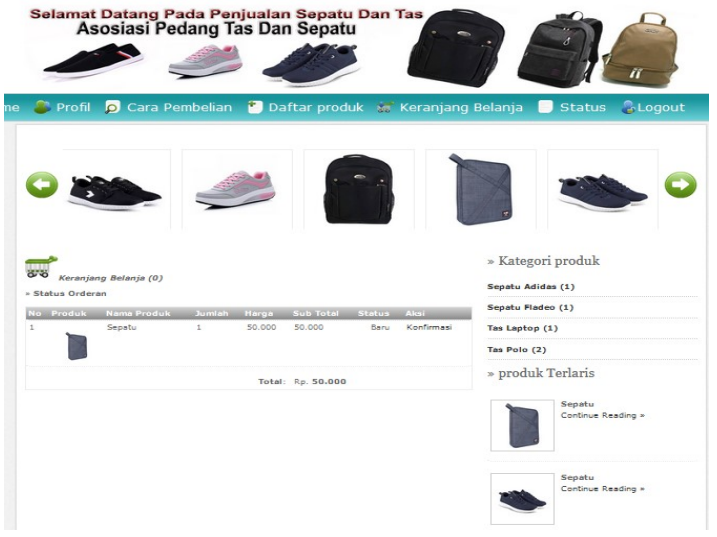

Layout Menu Status Order

\section{KESIMPULAN}

Sehubungan dengan analisa yang dilakukan pada Asosiaasi Pedagang Sepatu dan Tas tentang permasalahan pemesanan produk obat dan peralatan pertanian dengan metode penelitian yang telah diuraikan pada bab-bab sebelumnya, maka dapat diambil kesimpulan sebagai berikut:
1. Dengan Perancangan Website dapat meningkatan produktifitas penjualan produk pada Asosiaasi Pedagang Sepatu dan Tas.

2. Dengan menggunakan Website dapat memudahkan promosi atau pemasaran produk pada Asosiaasi Pedagang Sepatu dan Tas.

3. Dengan menggunakan Website sebagai penjulan memudahkan customer dalam memesan produk tanpa harus datang ke toko.

4. Dengan rancangan sistem yang baru, pembuatan laporan-laporan yang berhubungan dengan informasi penjualan dapat dibuat secara cepat, tepat dan dapat meminimalkan kesalahankesalahan.

\section{REFERENSI}

A.S. Rosa dan M. Salahuddin. 2011. Modul Pembelajaran Rekayasa Perangkat Lunak (Terstrukturdan Berorientasi Objek). Bandung : Modula

Madcoms. 2011.Membongkar Misteri Adobe Dreamweaver CS6 dengan PHP \& MySQL. Yogyakarta: CV Andi Offset.

Madcoms. 2012. Adobe Dreamweaver CS6 \& PHP - MySQL Untuk Pemula. Yogyakarta: CV Andi Offset.

Sibero, F.K. Alexander. 2011. Kitab Suci Web Programming. Yogyakarta: MediaKom

Sutabri, Tata. 2012. Analis Sistem Informasi. Yogyakarta: CV Andi Offset. Tantra, Rudy.2012. Manajemen Proyek Sistem Informasi.Yogyakarta : CV Andi Offse 